\title{
Investigation of Certain Manifestations of Bystander Response Phenomenon That May Affect the Development of Human Cancer Pathology
}

\author{
Maria A Pilinska* and Olena V Shemetun \\ State Institution National Research Center for Radiation Medicine of the National Academy of Medical Sciences of Ukraine, \\ Ukraine
}

*Corresponding author: Maria A Pilinska, State Institution National Research Center for Radiation Medicine of the National Academy of Medical Sciences of Ukraine, 53 Yuriia Illienka St., Kyiv, 04050, Ukraine

\begin{tabular}{|c|c|}
\hline ARTICLE INFO & ABSTRACT \\
\hline Received: 齒 January 24, 2021 & $\begin{array}{l}\text { Abbreviations: RIBE: Radiation-Induced Bystander Effects; TIBE: Tumor-Induced } \\
\text { Bystander Effects; RIRE: Radiation Induced Rescue Effect; CLL: Chronic Lymphocytic }\end{array}$ \\
\hline Published: 蔧 February 04, 2021 & Leukemia; PBL: Peripheral Blood Lymphocytes \\
\hline
\end{tabular}

Citation: Maria A Pilinska, Olena V Shemetun. Investigation of Certain Manifestations of Bystander Response Phenomenon That May Affect the Development of Human Cancer Pathology. Biomed J Sci \& Tech Res 33(4)-2021. BJSTR. MS.ID.005434.

\section{Short Communication}

To manifestations of the universal phenomenon "bystander response" as the response of normal recipient cells (cellsbystanders) on the interaction with damaged donor cells (cellsinductors) belong radiation-induced and tumor-induced bystander effects (RIBE and TIBE respectively) which can play a significant role in the development of human cancer pathology [1-3]. It is believed that RIBE and TIBE not only can increase the risk of its occurrence, but also contribute to the realization of secondary malignant neoplasms in cancer patients, which aggravates the prognosis for the future health and subsequent survival of such patients [4-6]. Negative contribution for patients with malignant tumors also can have the radiation induced rescue effect (RIRE), because under their realization malignant cells may be affected by feedback signals from normal cells, which can increase the activation of repair systems, thereby reducing the effectiveness of cancer therapy, which is especially dangerous for children and young contingents of oncological patients [7]. The urgency of the problem of interaction between malignantly transformed and normal cells for human health stimulated our experimental research in this area [8-10]. Because the characteristic feature of the bystander response phenomenon is an increase of chromosomal instability in the bystander cells, the effects of the interaction between malignant (non-irradiated or irradiated in vitro) and normal human somatic cells we assessed by cytogenetic markers of genome stability level.

\section{Materials and Methods}

As a model of malignant cells-inductors the hematopoietic cells from untreated patients with B-cell chronic lymphocytic leukemia (CLL) - non-irradiated (to identify TIBE) and irradiated in vitro at Go phase of mitotic cycle by $237 \mathrm{Cs}$ gamma quanta at a dose of 0.50 Gy (to identify RIBE) were used as a model of intact cells-bystanders normal peripheral blood lymphocytes (PBL) of relatively healthy individuals were applied. Study of the consequences of the interaction between these cells was performed on our own model system of co-cultivation the PBL obtained from individuals of different sexes, which allowed to distinguish inducers cells from cells-bystanders by the presence or absence of male sex chromosome Y. 


\section{Results}

It was found that co-cultivation of non-irradiated blood cells received from untreated CLL patients (cells-inductors) jointly with intact PBL received from conditionally healthy individuals (bystander cells) leads to significant increase $(p<0.01)$ in the meangroup frequency of chromosomal aberrations in the bystander cells - from $1.52 \pm 0.30$ per 100 metaphases (at the separate cultivation) to $3.31 \pm 0.50$ per 100 metaphases (at the joint cultivation) which confirmed the development of TIBE [8]. Under co-cultivation of irradiated in vitro malignant cells-inductors jointly with normal bystander cells the mean group frequency of chromosome aberrations in the bystander cells ( $5.18 \pm 0.51$ per 100 metaphases) became significantly higher than their background level $(1.52 \pm$ 0.30 per 100 metaphases, $p<0.001$ ) and their level at only TIBE manifestation (3.31 \pm 0.50 per 100 metaphases, $p<0.01$ ) [9]. The data obtained testify the reality of synergism between tumorinduced and radiation-induced bystander effects. Co-cultivation of irradiated in vitro blood cells of CLL patients with intact PBL of relatively healthy persons leads to the significantly decrease of chromosomal aberrations frequency in cells-inductors (from $12,88 \pm 1,16$ till $9,56 \pm 1,01$ per 100 metaphases, $p<0.01$ ), which is similar to the manifestation of rescue effect [10].

\section{Conclusion}

The results of our experimental studies concerning the interaction between irradiated or non-irradiated malignantly transformed and intact normal human somatic cells confirm the possibility of development the dangerous for cancer patients' certain manifestations of the bystander response phenomenon (TIBE, RIBE, RIRE), which requires further research for improvement the protocols of cancer treatment through the creation of more effective and less toxic therapy regimens.

\section{ISSN: 2574-1241}

DOI: 10.26717/BJSTR.2021.33.005434

Maria A Pilinska. Biomed J Sci \& Tech Res

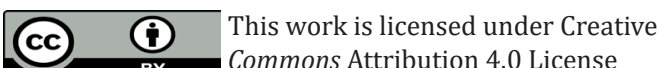

Submission Link: https://biomedres.us/submit-manuscript.php

\section{References}

1. Verma N, Tiku AB (2017) Significance and nature of bystander responses induced by various agents. Mutat Res 773: 104-121.

2. Burdak Rothkamm S, Rothkamm K (2018) Radiation-induced bystander and systemic effects serve as a unifying model system for genotoxic stress responses. Mutat Res 778: 13-22.

3. Shemetun OV, Pilinska MA (2019) Radiation-induced bystander effect - modeling, manifestation, mechanisms, persistence, cancer risks (literature review). Problems of Radiation Medicine and Radiobiology 24: 65-92.

4. Wang R, Zhou T, Liu W, Zuo L (2018) Molecular mechanism of bystander effects and related abscopal/cohort effects in cancer therapy. Oncotarget $9(26):$ 18637-18647.

5. Lee JS, Du Bois SG, Coccia PF, Bleyer A, Olin RL, et al. (2016) Increased risk of second malignant neoplasms in adolescents and young adults with cancer. Cancer 122(1): 116-123.

6. He X, Wu W, Ding Y, Li Y, Si J, et al. (2018) Excessive risk of second primary cancers in young-onset colorectal cancer survivors. Cancer Med 7(4): 1201-1210.

7. Kwan Ngok Yu (2019) Radiation-induced rescue effect. Journal of Radiation Research 60(2): 163-170.

8. Pilinska MA, Shemetun OV, Talan OA, Dibska OB, Kravchenko SM, et al. (2020) Cytogenetic effects in mixed culture of blood cells from patients with chronic lymphocytic leukemia with blood lymphocytes of healthy individuals. Dopov. Nac. akad. nauk Ukr 7: 86-93.

9. Pilinska MA, Shemetun OV, Talan O A, Dibska OB, Kravchenko SM, et al. (2020) Study the effects of ionizing radiation on the level of chromosome instability in human somatic cells during the development of tumor-induced bystander effect. Problems of Radiation Medicine and Radiobiology 25: 313-321.

10. Shemetun OV, Talan OA, Dibska OB, Pilinska MA (2020) Realization of the rescue effect at cytogenetic level due to the interaction between intact normal and irradiated malignant human blood lymphocytes. Dopov. Nac. akad. nauk Ukr 10: 77-84.

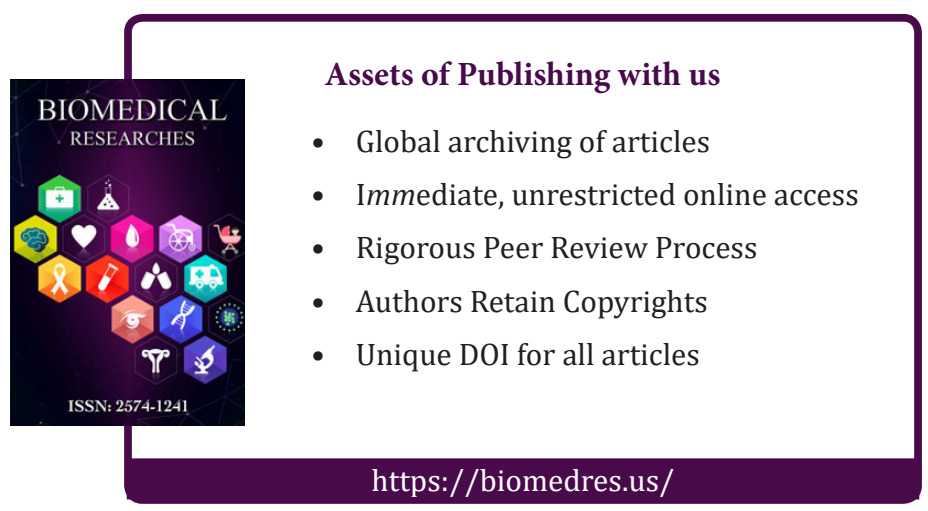

